\title{
ANALYSIS OF THE INFLUENCE OF AGRICULTURAL AND NON- AGRICULTURAL SECTORS PERFORMANCE ON THE NIGERIAN ECONOMY (1986-2004)
}

\author{
V. E. ENYA and M. BIME
}

(Received 25 January, 2007; Revision Accepted 28 June, 2007)

\begin{abstract}
This paper examines the influence of agricultural and non-agricultural economies on Nigeria's total economy. Time series data such as Nigeria's total GDP, Agricultural GDP and non-agricultural GDP were obtained. A double logarithm and exponential functions were used to estimate the elasticity and growth rate of each sector and the economy as a whole. The results revealed that a \% change in Agricultural and Non-agricultural sectors caused the Nigerian economy to change by $0.24 \%$ and $0.746 \%$ respectively. The agricultural, non-agricultural sector and the entire economy grew at the rate of $0.04 \%, 0.124 \%$ and $0.102 \%$ respectively during the study period.
\end{abstract}

KEY WORDS: Agricultural sector, Non-agricultural sector, Nigerian economy.

\section{INTRODUCTION}

Agricultural, is not only the major source of economic resilience, but also the main stay of most underdeveloped economics (Ojo and Akanji 1996, Onyeweaku and Nwaru 2005). Agricultural is so important that economist consider its development an one of the necessary per-condition for general or overall economic development.

Agricultural economic development entails a sustained increase in productivity of agricultural resources (land, capital, labour, and management) over a long period of time. Agricultural development also involves the outward movement of agricultural output and agricultural capital stock and efficient allocation and utilization of agricultural resources while economic development entails a sustained increase in real per capital productivity (Fajana, OSagie, Obi and Akata 1990 and Mellor 1995).

Rising agricultural productivity provide not only sufficient quantity but good quality food for the development of the non-agricultural sector, provide market for the product of industrial sector, and provide capital for the development of other sectors (Essien 2006 and Mellor 1995). The Nigerian agricultural economy has not been able to produce sufficient and good quality food for her 9ver 100 million and pressure on wage increase over the year in Nigeria. During the early stage of Nigerian economic development, $74 \%$ of foreign exchange came from agricultural, and was used to develop the petroleum industry (Ekpeyong, 1992, Ayinmodu, 1986). As at 1997 the growth rate of agricultural GDP was 5.9\% while petroleum GDP grew at an annual rate of $8.38 \%$. Available statistics shows that in the 1960s Nigeria was virtually self sufficient in food production and her agricultural contribution to total GDP was $60 \%$ annually. This declined to about $30-40 \%$ between 1970 and 1992 (Eyo, 1997).

Since the discovery of oil, Nigerian agricultural has been losing her workers to the non-agricultural sector due to poor wages and poor infrastructure in the sector. This has been evidenced by the massive rural-urban migration. Economic historians such as Norton, Alwang and Mellor agreed that there can be tangible economic development of any nation without a sire in agricultural productivity preceding or supporting a sustained that the agricultural industrial development. They also upheld that sustained development requires that the agricultural sector should release part of her labour force to non-agricultural sector, thereby permitting those remain9ing to re-organize their farms into a large mechanized operating unit. As the non-agricultural sector develops and begins to contribute to the national economy, the percentage contribution (not absolute contribution) of agricultural sector declines. (Mellor 1995, Norton and Alwang 1993). They also opined that as the National economy develops the percentage contribution of agricultural sector declines. It means that in a growing economy the contribution of agricultural increases in a decreasing rate. But in Nigeria's case the decline is not as a result of economic development, but due to neglect. This paper analysis the contribution of agricultural and nonagricultural sectors on the overall economic growth and derive some policy implication.

\section{METHODOLOGY}

Published time series data from 1986 to 2004 was used in this study. Specific data of interest include the annual Gross Domestic Product (GDP) of Nigeria, Agricultural Gross Domestic Product (GDP) and NOn-agricultural Gross Domestic Product (GDP) at factor cost. These data were collected from Bullion, a publication of Central Bank of Nigeria (CBN) 1997, CBN Annual Report and Statement of Accounts (1997, 2003, 2004), CBN statistical Bulletin 2003. Descriptive statistics such as average and percentage were used to analyze data. Double logarithm regression function was fitted to estimate the elasticity of the economy. Exponential regression function was also fitted to estimate the growth rate of Agricultural, Nonagricultural sectors and the economy as a whole

$$
\begin{aligned}
& \text { Double Log function } \\
& Y_{t}=f\left(X_{1}, X_{2}\right) \\
& \ln Y_{t}=\operatorname{lnbo}+\operatorname{Inbo}_{1} X_{1}+\ln b_{2} X_{2}+U \\
& Y_{t}=\text { Total GDP (a measure of the whole economy) } \\
& \mathrm{X}_{1}=\text { Agricultural GDP (a measure of agricultural sector) } \\
& \mathrm{X}_{2}=\text { Non-agricultural GDP (a measure of non- } \\
& \text { agricultural sector } \\
& =\text { Error term }
\end{aligned}
$$

$b_{1}=$ are the elasticity's of the economy in respect to agricultural and non-agricultural sectors respect respectively.

$$
\begin{aligned}
& \text { Exponential Function } \\
& Y_{t} \quad=f(T) \\
& \operatorname{InY} \quad=\mathrm{b} O=\mathrm{b}_{1} \mathrm{~T}+\mathrm{U} \\
& Y_{\mathrm{t}} \quad=\text { GDP for agric., non-agric and the economy as a } \\
& \text { whole } \\
& \mathrm{T} \quad=\text { Time trend } \\
& b_{1}=\text { Growth rate for agric, non-agric sectors and the }
\end{aligned}
$$




\section{RESULTS AND DISCUSSION}

Three tables are presented in this section for the purpose of discussion. Table 1 shows the trend of the percentage contribution of Agriculture GDP and NonAgricultural GDP and their averages over time. Table 2 indicates the influence of agricultural and non-agricultural sector in the Nigerian economy. Table 3 shows the growth of agricultural sector, non-agricultural sector and the entire economy.

Table 1: percentage contribution of agricultural and nonagricultural sectors to the economy

\begin{tabular}{|l|l|l|}
\hline Years & Agric. GDP (\%) & Non-agric GDP(\%) \\
\hline 1986 & 42.7 & 57.3 \\
\hline 1987 & 14.6 & 58.5 \\
\hline 1988 & 41.5 & 58.5 \\
\hline 1989 & 40.6 & 59.4 \\
\hline 1990 & 39.0 & 61.0 \\
\hline 1991 & 39.0 & 61.0 \\
\hline 1992 & 38.0 & 62.0 \\
\hline 1993 & 38.0 & 62.0 \\
\hline 1994 & 38.0 & 62.0 \\
\hline 1995 & 38.0 & 62.0 \\
\hline 1996 & 39.0 & 61.0 \\
\hline 1997 & 39.0 & 61.0 \\
\hline 1998 & 40.0 & 60.0 \\
\hline 1999 & 42.0 & 58.0 \\
\hline 2000 & 15.0 & 85.0 \\
\hline 2001 & 15.0 & 85.0 \\
\hline 2003 & 14.0 & 86.0 \\
\hline 2004 & 14.0 & 86.0 \\
\hline Average & 32.0 & 42.7 \\
\hline & & \\
\hline
\end{tabular}

Sources: computed from Bullion of CBN (1997), CBN Annual Report and Statement of Account (1997, 2003, 2004) and CBN Statistical Bulletin (2004).

Table 1 above shows a declining trend of the percentage contribution of agricultural sector to the economy. With an average annual \% contribution of about 32\%, the \% contribution of agricultural declined from $42.7 \%$ in 1986 to about $14 \%$ in 2004 . The table also revealed a rising trend of the $\%$ contribution of the Non-agricultural sector to the economy indicating an average annual \% contribution of $68 \%$ to the economy. The \% contribution of the Non-agricultural sector increased from $57.2 \%$ in 1968 to $86.2 \%$ in 2004 .

Table 2: Regression Result indicating the influence of Agricultural and Non-Agricultural sectors on Nigerian Economy

\begin{tabular}{|l|l|l|}
\hline Variables & Coefficient & t-ratios \\
\hline Constant & 0.668 & 2.570 \\
\hline Agric. Sector $\left(\mathrm{x}_{1}\right)$ & 0.243 & $2.545^{\star}$ \\
\hline $\begin{array}{l}\text { Non-Agric Sector }\left(\mathrm{X}_{2}\right) \\
\mathrm{R}^{2}=0.996\end{array}$ & $0 . .743$ & $29.2^{\star \star}$ \\
\hline
\end{tabular}

*significant at $5 \%$ level

**significant at $1 \%$ level

From the regression result in table 2 above the t-ratio for Agricultural sector is 2.545 while that of Non-agricultural sector is 29.22. These showed that Agricultural sector and Non-agricultural sector had a positive influence on the economy at $5 \%$ and $1 \%$ level of significance respectively. The elasticity of the economy with respect to agricultural GDP and Non-agricultural GDP is $0.243 \%$ and $0.743 \%$ respectively. This implies that a \% change in the agricultural GDP, Nonagricultural GDP led to a $0.243 \%$ and $0.743 \%$ change in the economy respectively. It means that the economy is inelastic with respect to agricultural and non-agricultural sector performance. The economy is more inelastic with respect to agricultural production than non-agricultural production. In countries where economies are allowed to develop properly, declining \% contribution of agricultural sector does not cause unemployment and lack of food because of non-agricultural sector is viable enough to absorb the labour agricultural sector releases, and to provide the enabling environment for those remaining in the sector to reorganize their farms into a more efficient large scale operating unit. This study revealed that the reverse is the case in Nigeria.

Table 3: Regression result indicating growth of agricultural, non-agricultural sectors and the entire economy.

\begin{tabular}{|l|l|l|lc|}
\hline Variable & Bo & B1 $^{`}$ & $\mathbf{R}^{2}$ & t \\
\hline Agricultural sector & 28.5 & 0.04 & 0.99 & $34.4^{\star \star}$ \\
Non-agricultural sector & 25.94 & 0.124 & 0.76 & $7.2^{\star \star}$ \\
Entire economy & 49.3 & 0.102 & 0.77 & $7.6^{\star \star}$ \\
\hline
\end{tabular}

** Significant at $1 \%$ level.

The regression result in table 3 above shows a t-ratio of 34.4, 7.2 and 7.6 for Agricultural sector, Non-agricultural sector and the entire economy respectively.

The result indicated that time variable had a positive and significant effect on Agricultural sector, Non-agricultural sector and the entire economy at $1 \%$ level. The result also indicated that during the period under study agricultural, nonagricultural sectors and the whole economy grew at the rate of $0.04 \%, 0.124 \&$ and $0.102 \%$ respectively. Although the nonagricultural sector grew faster than the agricultural sector, its growth was still very poor. The release of labour from agricultural sector to the non-agricultural sector without a corresponding empowerment of the remaining people in the sector was responsible for its poor performance. Further more; the high level of labour releases from agricultural sector as evidenced by the massive rural-urban drift could not be absorbed by the slow expansion of the non-agricultural sector. The poor performance of both sectors was responsible for the slow growth of the economy which grew at the rate of $0.103 \%$ during the study period. The inability of the non-agricultural sector to absorb the labour released by the agricultural sector is the major cause of employment and shortage of food in Nigeria.

\section{RECOMMENDATIONS}

The study recommends that more rural infrastructure be provided to reduce the high level of rural urban drift which cause scarcity of labour at the rural areas. Farm should be reorganized into a more efficient large scale mechanized operating unit. Input of new and improved forms (high yielding seeds and fertilizers), institution for servicing agricultural production such as credit, marketing agencies and rural governmental bodies for fostering collective action in building feeder roads and rural projects should be provided. All enabling environment that will attract both foreign and local investors into the non-agricultural sector should be put in place to enable it absorb labour released from the agricultural sector.

\section{CONCLUSION}

The study revealed that the growth of the nonagricultural sector was not enough to absorb the release of labour from agricultural sector. This resulted in unemployment, shortage of food and poor performance of the entire economy.

\section{REFERENCES}

Ayinmodu, M. S., 1986. The role of River Basin Development Authority in food production. Proceedings of Farm Management Association of Nigeria 1:73 Central Bank of Nigeria Annual Report and Statement of Account 1997, 2003 and 2004.

Central Bank of Nigeria Statistical Bulletin 2003, 2004.

Ekpenyong, D. B., 1992. Exporting Financing: A Guide for Nigerian Exporters. The Nigerian Bankers. (1), 1:13. 
Eyo, E.E.C., 1991. Implication of Pricing for National Food Security. Billion publication of Central Bank of Nigeria 21 (2): $4-6$

Essien, E. A., 2006. Assessing Technical Efficiency in the Food Sector of Small and Medium Industries (SMI) in Nigeria. Farm Management Association of Nigeria (FAMAN) conference proceeding. 2006. pp $90-99$

Fajana, F., Osagie, E., Obi, A. W. and Akata, E. O., 1996. Economics: A preparatory course. Evans Brother (Nigeria publisher). Pp139 - 144.

Mellor, J. W., 1995. Introduction. Agriculture on the road to industrialization. John Hopkins University press pp1 6
Norton, G. W. and Alwang, J., 1993. Introduction to Economics of Agricultural Development. Mc. Graw-Hill. Inc. pp156 - 167

Ojo, M. O. and Akanji, O. O., 1996. The impact of Macroeconomic policy Reforms on Nigerian Agriculture. CBN Economic and Financial Review. (34) 2: $549-570$.

Onyenweaku, C. E. and Nwaru., 2005. Application of Stochastic Frontier production Functions to the Measurement of Technical Efficiency in Food production in Imo State". Nigerian Agricultural Journal. 36 (2005) $1-12$.

Onyenweaku, C. E., Agu, S. E. and Obasi, F. C., 2000. Economics of small - holder Rice Farming under different productions system in South Eastern Nigeria. Nigerian Journal of Agricbusiness and Rural development. Vol. 1. No. 1 